\title{
Hyperiid amphipods distribution between the central coast and oceanic islands off Chile, southeastern Pacific
}

\author{
Christian Véliz ${ }^{1}$, Armando Mujica ${ }^{1}$ \& María Luisa Nava ${ }^{1}$ \\ ${ }^{1}$ Departamento de Acuicultura, Universidad Católica del Norte, Coquimbo, Chile \\ Corresponding author: Armando Mujica (amujica@ucn.cl)
}

\begin{abstract}
The composition, distribution, and abundance of hyperiid amphipods collected in the oceanographic cruise between the central coast and oceanic islands of Chile in the southeastern Pacific were analyzed. Thirty-four genera and 54 species were identified, grouped into two infraorders and 16 families. The presence of Hemityphis tenuimanus Claus 1879, and Laxohyperia vespuliformis Vinogradov \& Volkov 1982, expands its geographical distribution as new records for the southeastern Pacific. According to the founded species, spatial distribution, and the bodies of water present in the study area, Chile's central region would be a transition zone for species originating from the Magellan Province (Subantarctic water) and the Peru-Chile Province (Subtropical water).
\end{abstract}

Keywords: Hyperiidea; pelagic amphipod; biodiversity; distribution; oceanic islands; southeastern Pacific.

\section{INTRODUCTION}

Hyperiidea is one of the four suborders in the order Amphipoda. They are zooplanktonic and very abundant (Bowman \& Gruner 1973, Shulenberger 1979, Vinogradov 1990, Palma \& Kaiser 1993). They play a unique and crucial ecological role in pelagic food webs (Palma \& Kaiser 1993, Vaske \& Castello 1998, Bocher et al. 2001, Koval \& Batischeva 2003, Klimpel \& Rückert 2005, Croxall 2006, Klimpel et al. 2008, Kosenok \& Naidenko 2008). Likewise, they constitute associations as parasitoids and commensals with various species of gelatinous zooplankton (Harbison et al. 1977, Laval 1980, 2001, Hurt et al. 2013).

On the coasts of Chile, foreign scientific expeditions that sporadically included the coasts of this country were the first identifications of this group. Among them were the "Challenger Expedition" (Stebbing 1888), which recorded the presence of Phronimopsis spinifera in the route between Tahiti and Juan Fernández, and Hyperia gaudichaudii in the Magallanes area. In the "Vagabondia Expedition" were collected Parathemisto gracilipes specimens, near to the Juan Fernández Archipelago (Meruane 1979).

The first study on hyperiid amphipods from Chilean waters was carried out off Punta Curaumilla, Valparaíso
(Meruane 1979). Fourteen species distributed in eight families and 12 genera were identified. Describing for the first time in Chilean waters Scina borealis, $S$. latifrons, Vibilia armata, Hyperia gaudichaudii, Hyperietta stephenseni, Lestrigonus schizogeneios, $L$. crucipes, Parathemisto gracilipes, Phronimopsis spinifera, Phronima sedentaria, Primno macropa, Eupronoe maculata, Tryphana malmii, and Streetsia porcella. Also, Scina latifrons and Lestrigonus crucipes were redescribed and quoted for the first time in the Pacific Ocean.

Meruane (1979) points out that the greatest abundance and species diversity coincides with periods of intense upwelling in the study area. Scina latifrons, Parathemisto gracilipes, Phronimopsis spinifera, Phronima sedentaria, and Primno macropa were found preferably between 0 and $50 \mathrm{~m}$ depth, Scina borealis and Hyperia gaudichaudii were in the subsurface stratum $(50-100 \mathrm{~m})$.

Meruane (1982) reported nine species (Vibilia stebbingi, Hyperietta stephenseni, Lestrigonus schizogeneios, L. crucipes, Phronimella elongata, Lycaeopsis sp., Tryphana malmii, Eupronoe maculata, Primno macropa) in the Juan Fernández Archipelago.

The southeastern Pacific's hydrological conditions have been characterized by several authors (Silva \&

Corresponding editor: Ingo Wehrtmann 
Sievers 1973, 1974, 1981, 1983, Sievers 1975, Silva, 1985, 1992, Moraga \& Olivares 1996, Schneider et al. 2007, Moraga \& Argandoña 2008). They have defined different flows and water bodies present between the oceanic islands and the South American coast.

In the study area, variable flow systems and counterflows in north and south directions ( 73 to $100^{\circ} \mathrm{W}$ ) have been described. Covering a wide area of the Pacific in which cold waters are separated from the warm ones moving in opposite directions and have been associated with the southwestern Pacific anticyclone dynamics (Brandhorst 1971, Silva \& Neshyba 1979, Mesias et al. 2003, Schneider et al. 2007).

All of the above accounts for the conceptual basis and background needed to study the composition, distribution, and abundance of hyperiid amphipods between Valparaíso and Juan Fernández Archipelago and Desventuradas Islands (San Félix and San Ambrosio islands), as well as their possible relationship with environmental conditions.

\section{MATERIALS AND METHODS}

During the CIMAR VI "Oceanic Islands" cruise (September-October 2000), zooplankton samples were obtained at 64 stations in the area between Valparaíso ( $33^{\circ} 01^{\prime}$ 'S, $\left.71^{\circ} 38^{\prime} \mathrm{W}\right)$, Juan Fernández Archipelago (Robinson Crusoe and Alejandro Selkirk islands)

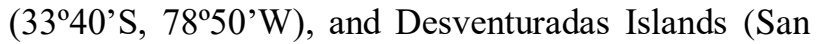
Félix and San Ambrosio islands) (26 $\left.20^{\circ} \mathrm{S}, 80^{\circ} 05^{\prime} \mathrm{W}\right)$ (Fig. 1). Bongo nets of $60 \mathrm{~cm}$ in diameter and $330 \mu \mathrm{m}$ of mesh opening were utilized dragged obliquely between $200 \mathrm{~m}$ deep to the surface.

The samples were preserved in a formalin solution and seawater (5\%). The amphipods were separated, counted, and identified based on specialized bibliography (Bowman \& Gruner 1973, Zeidler 1992, 1998, 2000, 2003, 2004, Vinogradov et al. 1996, Vinogradov 1999, Shih \& Hendrycks 2003). The amphipod abundance was standardized to $100 \mathrm{~m}^{-3}$ of water filtered by the net.

Each species' numerical dominance was determined from their abundance values (percentage ratio between each species' abundance and the total number of amphipods captured). Species frequency of occurrence was determined from the percent relationship between the number of stations in which each species was found and the total sampled stations. These values were classified according to the scale proposed by Bodenheimer (1955), which considers accidental $(<25 \%)$, accessory $(25-50 \%)$, and frequent $(>50 \%)$ species.
The amphipod species diversity was determined using the Shannon-Weaver index. The Euclidean distance index was used to determine the faunal similarity between stations and build the cluster using the Ward method's agglomerative strategy, which associates the values through variance analysis of the distances between clusters. Bootstrap probability (BP) was also used, together with the impartial alternative index (AU 95\%), using the R statistical program.

The oceanographic variables considered (temperature, salinity, and dissolved oxygen) were recorded using a CTDO-Seabird-25 profiling probe (Moraga \& Argandoña 2008). The surface records and the stratum between the surface and $200 \mathrm{~m}$ depth were considered for the analysis. The water masses were determined according to the mixing triangle graphic method (Mamayev 1975), using the original water types and temperature and salinity pairs for the mixing triangles as determined by Silva \& Konow (1975), and then graph them using the Surfer 7.0 program (Figs. 2-3).

\section{RESULTS}

Between Valparaíso and the Juan Fernández Archipelago (Transect A) between 0 and $200 \mathrm{~m}$ deep, a surface water mass, Subantarctic Surface Water (SASW), was detected, and under it, the Equatorial Subsurface Water (ESSW). In the stations near the continental coast, the upper limit of the ESSW was detected at $40 \mathrm{~m}$ depth, and the SASW increased its depth from east to west, exceeding $200 \mathrm{~m}$, near the archipelago, with a core (85\%) at $50 \mathrm{~m}$ deep, at station 7 (Fig. 1).

In Transect B stations (Juan Fernández Archipelago-Desventuradas Islands), surface $(0-200 \mathrm{~m})$, three water masses were detected, Subtropical Surface Water (STSW), SASW, and ESSW. From the north end of this transect to station 44, an intrusion of STSW was detected in the surface layer $(0-110 \mathrm{~m})$, decreasing its maximum depth from north to south. Under it, in the northern part and superficially, from station 44 to the south was the SASW was present, and under it, from station 47 to the south, the ESSW was detected (Fig. $2 b)$.

Eight hundred fourteen amphipods were identified from the samples, out of 929 captured, belonging to 54 species, two infraorders, 16 families, and 34 genera (Table 1). All identified species have been cited for the southeastern Pacific region, except for Hemityphis tenuimanus, which has only been found in the tropical zone of the Atlantic Ocean and the North Pacific central gyre (Vinogradov et al. 1996), and Laxohyperia vespuliformis, only reported in the North Pacific, south- 

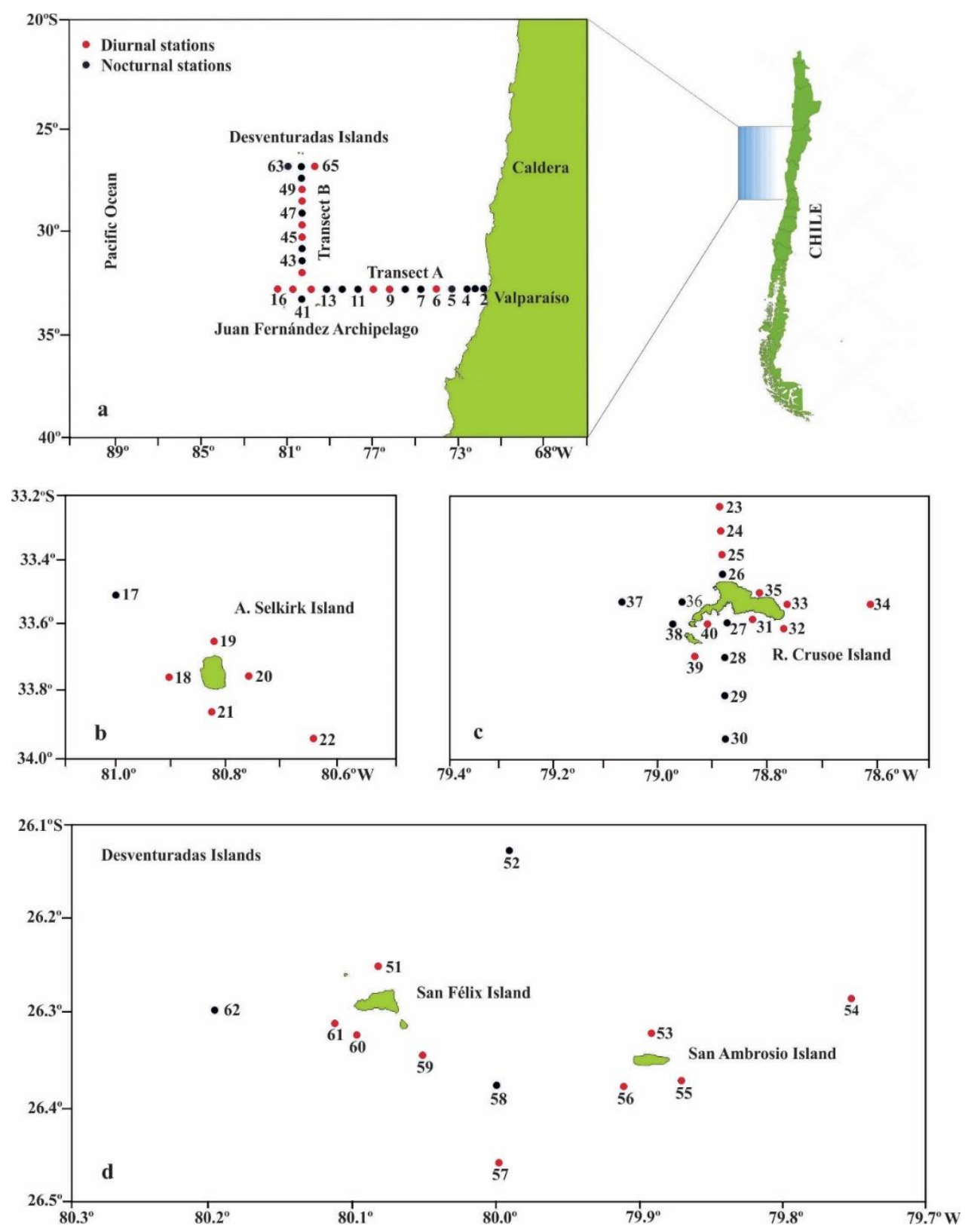

Figure 1. Location of sampling stations. a) Valparaíso to Juan Fernández Archipelago (Transect A), Juan Fernández Archipelago - Desventuradas Islands (Transect B), b) Alejandro Selkirk Island, c) Robinson Crusoe Island, d) Desventuradas Islands.

western Atlantic and China Sea (Vinogradov et al. 1996, Lima \& Valentin 2001).

The highest abundances were found in stations 7,47 and 64 (>60 specimens $\left.100 \mathrm{~m}^{-3}\right)$, stations located far from the continental and insular coasts, except station 64, located between San Félix and San Ambrosio islands (Fig. 1, Table 2). All of these stations were sampled in darkness hours. The lowest abundances $(<4$ specimens $100 \mathrm{~m}^{-3}$ ) were found in stations near the continental and insular coast, sampled mainly during daylight hours (Table 2).
The highest species richness values ( $\geq 20 \mathrm{spp}$.) were found in stations 7 (Transect A), and stations 47, 54, 58, 63, and 64, in the northern half of Transect B or around of Desventuradas Islands, which partially coincides with the greater abundances of total amphipods. The lowest species richness (1-2 spp.) was found in the stations $2,18,20,27$, and 39. The first one is located on the coast of Valparaíso and the remaining ones near the A. Selkirk Island and Juan Fernández Archipelago (Fig. 1, Table 2). 

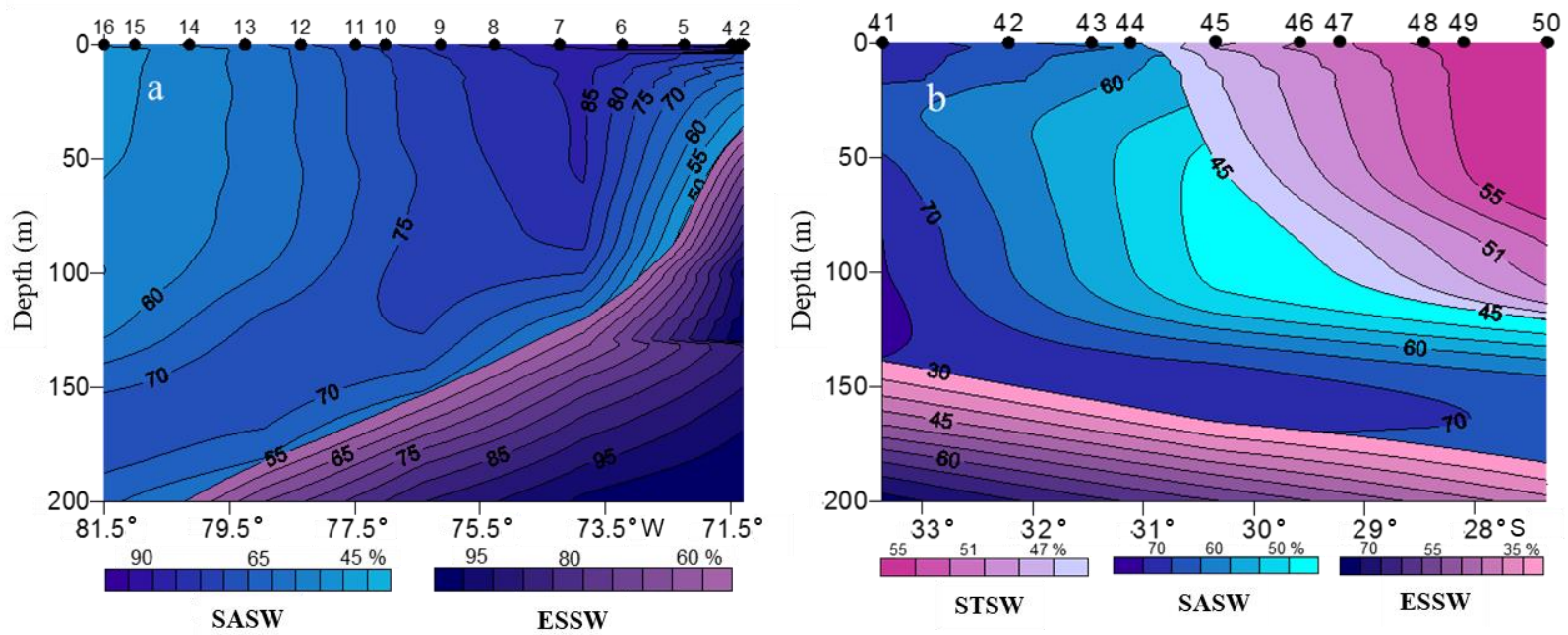

Figure 2. Water masses in percentage of composition. a) Valparaíso-Juan Fernández Archipelago transect, b) Juan Fernández Archipelago-Desventuradas Islands transect. (SASW: Subantarctic Surface Water, ESSW: Equatorial Subsurface Water, STSW: Subtropical Surface Water).

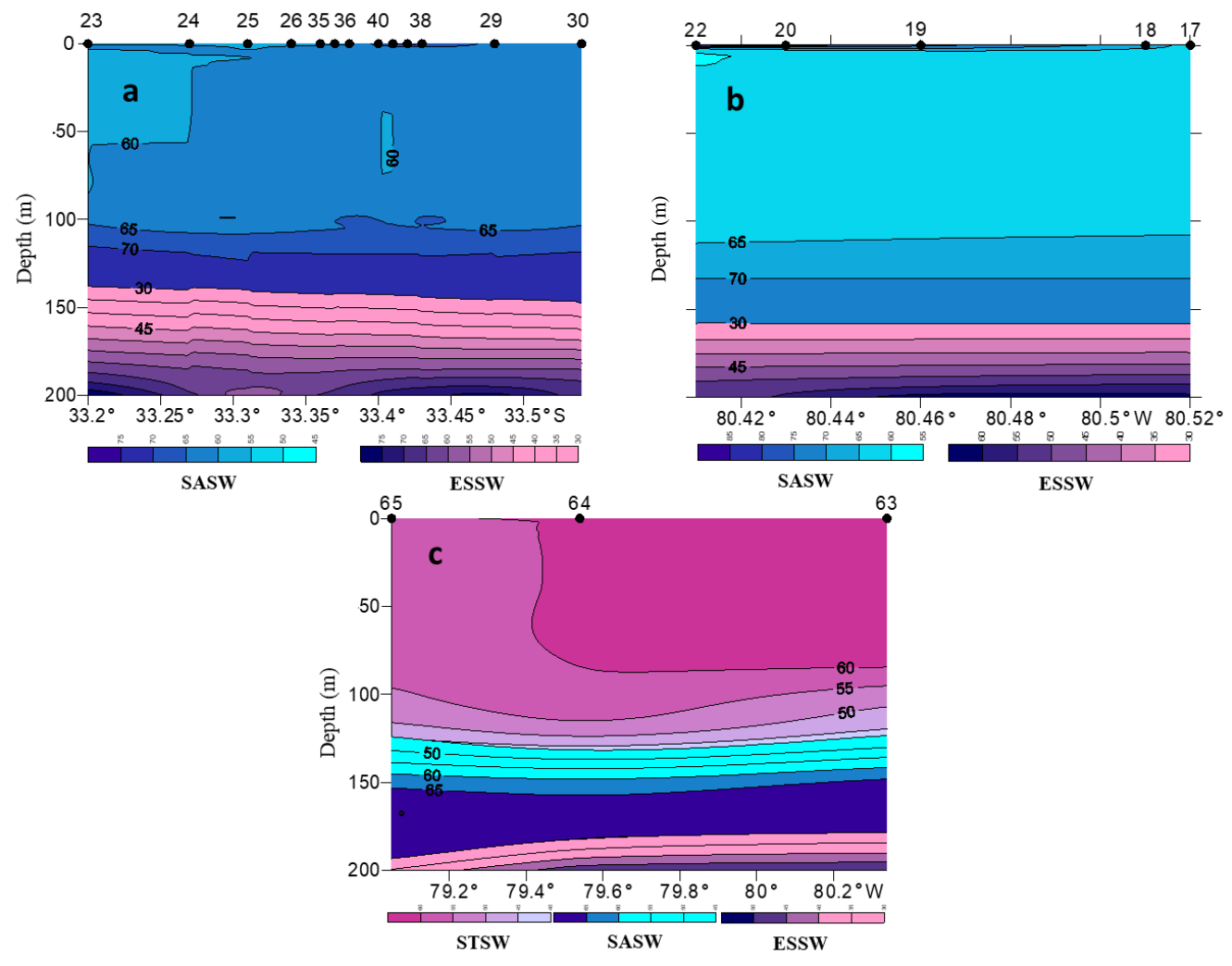

Figure 3. Water masses (\%) present in oceanographic stations around a) Juan Fernández Archipelago, b) Alejandro Selkirk Island, and c) Desventuradas Islands. (SASW: Subantarctic Surface Water, ESSW: Equatorial Subsurface Water, STSW: Subtropical Surface Water).

The greatest diversities (>3 bits) were detected in stations located in the middle part of Transect B and among San Félix and San Ambrosio islands (St. 47, 58, and 64), which coincide with the highest values of species richness (Table 2, Fig. 1). 
Table 1. Identified species in the study area (WoRMS 2020).

\begin{tabular}{|c|c|}
\hline Infraorden Physosomata Pirlot, 1929 & Family Phrosinidae Dana 1852 \\
\hline Family Scinidae Bowman \& Gruner 1973 & Anchylomera blossevillei Milne-Edwards 1830 \\
\hline Acanthoscina acanthodes (Stebbing 1895) & Primno macropa Guérin-Méneville 1836 \\
\hline Scina stenopus Stebbing 1895 & Primno brevidens Bowman 1978 \\
\hline Scina borealis (Sars 1882) & Primno latreillei Stebbing 1888 \\
\hline Scina crassicornis (Fabricius 1775) & Phrosina semilunata Risso 1822 \\
\hline Scina curvidactyla Chevreux 1914 & Family Anapronoidae Bowman \& Gruner 1973 \\
\hline Scina latifrons Wagler 1926 & Anapronoe reinhardti Stephensen 1925 \\
\hline Scina stebbingi Chevreux 1919 & Family Tryphanidae Boeck 1870 \\
\hline Scina submarginata Tattersall 1906 & Tryphana malmii Boeck 1870 \\
\hline Scina tullbergi (Bovallius 1885) & Family Brachyscelidae Stephensen 1923 \\
\hline Family Lanceolidae Bovallius 1887 & Brachyscelus crusculum Bate 1861 \\
\hline Lanceola pacifica Stebbing 1888 & Family Lycaeopsidae Chevreux 1913 \\
\hline Infraorder Physocephalata Bowman \& Gruner 1973 & Lycaeopsis themistoides Claus 1879 \\
\hline Family Vibiliidae Dana 1852 & Family Eupronoidae Zeidler 2016 \\
\hline Vibilia armata Bovallius 1887 & Eupronoe minuta Claus 1879 \\
\hline Vibilia stebbingi Behning \& Woltereck 1912 & Eupronoe armata Claus 1879 \\
\hline Vibilia australis Stebbing 1888 & Parapronoe crustulum Claus 1879 \\
\hline Family Paraphronimidae Bovallius 1887 & Parapronoe parva Claus 1879 \\
\hline Paraphronima gracilis Claus 1879 & Family Lycaeidae Claus 1879 \\
\hline Family Hyperiidae Dana 1852 & Lycaea serrata Claus 1879 \\
\hline Laxohyperia vespuliformis Vinogradov \& Volkov 1982 & Simorhinchotus antennarius (Claus 1871) \\
\hline Parathemisto (Euthemisto) gaudichaudi (Guérin 1825) & Family Oxycephalidae Dana 1852 \\
\hline Family Lestrigonidae Zeidler 2004 & Oxycephalus piscator Milne-Edwards 1830 \\
\hline Themistella fusca (Dana 1852) & Streetsia porcella (Claus 1879) \\
\hline Hyperioides longipes Chevreux 1900 & Calamorhynchus pellucidus Streets 1878 \\
\hline Hyperietta stephenseni Bowman 1973 & Glossocephalus milneedwardsi Bovallius 1887 \\
\hline Hyperietta stebbingi Bowman 1973 & Rhabdosoma armatum (Milne-Edwards 1840) \\
\hline Phronimopsis spinifera Claus 1879 & Family Platyscelidae Bate 1862 \\
\hline Lestrigonus bengalensis Giles 1887 & Hemityphis tenuimanus Claus 1879 \\
\hline Lestrigonus crucipes (Bovallius 1889) & Paratyphis maculatus Claus 1879 \\
\hline Lestrigonus schizogeneios (Stebbing 1888) & Tetrathyrus forcipatus Claus 1879 \\
\hline Family Phronimidae Rafinesque 1815 & Family Amphithyridae Zeidler 2016 \\
\hline Phronima curvipes Vosseler 1901 & Amphithyrus bispinosus Claus 1879 \\
\hline Phronima sedentaria (Forskal 1775) & Amphithyrus sculpturatus Claus 1879 \\
\hline Phronima pacifica Streets 1877 & Family Parascelidae Claus 1879 \\
\hline Phronimella elongata (Claus 1862) & Parascelus edwardsi Claus 1879 \\
\hline
\end{tabular}

Other high diversity values ( $\geq 2.5$ bits) were detected in stations in the northern part of the study area, except for stations 7 and 22, located in the middle part of Transect A and southwest of A. Selkirk Island, respectively (Table 3 , Fig. 1). The correspondence of these high diversity values with the greatest species richness $(\geq 20)$, have as an exception, what was registered in station 22 , with a diversity of 2.63 bits and richness of 15 species (Table 2).

In the stations 18 and 27, located to the west of A. Selkirk Island and to the south of R. Crusoe Island, specimens of a single species were captured, so diversity was not determined.

Of the 54 identified species, five of them (Themistella fusca, Hyperietta stephenseni, Lestrigonus schizogeneios, Phrosina semilunata, Eupronoe armata) had numerical dominance over 5\%, and the sum of their abundances represent more than half of the total amphipods captured. Of these, $T$. fusca, $P$. semilunata, and $E$. armata were the species with the highest frequency of occurrence $(>59 \%$, Table 3$)$ and the presence of the other two (H. stephenseni and $L$. schizogeneios) listed as an accessory (25-50\%), as well as Vibilia armata, V. stebbingi, Hyperietta stephenseni, Lestrigonus crucipes, Phronima curvipes, $P$. sedentaria, Phronimella elongata, Primno macropa, $P$. brevidens, Tryphana malmii, Lycaeopsis themistoides, Eupronoe minuta, Calamorhynchus pellucidus, and Hemityphis tenuimanus, with dominance between 2.1 and $3.6 \%$ (Table 3 ). 
Table 2. Abundance (ind $100 \mathrm{~m}^{-3}$ ), amphipod richness, and diversity.

\begin{tabular}{|c|c|c|c|c|c|c|c|}
\hline Station & Abundance & Richness & Diversity & Station & Abundance & Richness & Diversity \\
\hline 2 & 2 & 2 & 0.69 & 34 & 22 & 11 & 2.29 \\
\hline 3 & 11 & 4 & 1.12 & 35 & 11 & 7 & 1.77 \\
\hline 4 & 13 & 8 & 1.93 & 36 & 18 & 7 & 1.53 \\
\hline 5 & 18 & 11 & 1.83 & 37 & 17 & 12 & 2,34 \\
\hline 6 & 30 & 14 & 2.41 & 38 & 13 & 6 & 1.61 \\
\hline 7 & 68 & 23 & 2.54 & 39 & 4 & 2 & 0.69 \\
\hline 8 & 23 & 14 & 2.48 & 40 & 6 & 3 & 1.10 \\
\hline 9 & 4 & 3 & 1.04 & 41 & 9 & 6 & 1.68 \\
\hline 10 & 25 & 10 & 1.97 & 42 & 14 & 10 & 2.17 \\
\hline 11 & 21 & 13 & 2.43 & 43 & 24 & 12 & 2.24 \\
\hline 12 & 5 & 4 & 1.33 & 44 & 18 & 9 & 1.72 \\
\hline 13 & 13 & 11 & 2.35 & 45 & 28 & 15 & 2.50 \\
\hline 14 & 12 & 7 & 1.97 & 46 & 26 & 18 & 2.76 \\
\hline 15 & 20 & 12 & 2,29 & 47 & 64 & 31 & 3.03 \\
\hline 16 & 11 & 7 & 1.80 & 48 & 36 & 18 & 2.65 \\
\hline 17 & 7 & 7 & 1.95 & 49 & 35 & 17 & 2.61 \\
\hline 18 & 1 & 1 & 0.00 & 50 & 31 & 10 & 1.73 \\
\hline 19 & 12 & 9 & 2.10 & 51 & 10 & 9 & 2.16 \\
\hline 20 & 4 & 2 & 0.56 & 52 & 12 & 10 & 2.25 \\
\hline 21 & 7 & 5 & 1.48 & 53 & 17 & 10 & 2.18 \\
\hline 22 & 19 & 15 & 2.63 & 54 & 38 & 21 & 2.82 \\
\hline 23 & 19 & 12 & 2.36 & 55 & 3 & 3 & 1.10 \\
\hline 24 & 18 & 6 & 1.63 & 56 & 9 & 8 & 2.04 \\
\hline 25 & 13 & 8 & 1.93 & 57 & 12 & 8 & 1.94 \\
\hline 26 & 17 & 11 & 2.31 & 58 & 30 & 23 & 3.06 \\
\hline 27 & 1 & 1 & 0.00 & 59 & 8 & 7 & 1.91 \\
\hline 28 & 16 & 9 & 1.84 & 60 & 10 & 7 & 1.89 \\
\hline 29 & 16 & 9 & 2.08 & 61 & 9 & 5 & 1.30 \\
\hline 30 & 20 & 14 & 2.51 & 62 & 10 & 7 & 1.83 \\
\hline 31 & 10 & 5 & 1.61 & 63 & 29 & 20 & 2.85 \\
\hline 32 & 7 & 3 & 1.08 & 64 & 61 & 26 & 3.08 \\
\hline 33 & 15 & 8 & 1.99 & 65 & 19 & 14 & 2.55 \\
\hline
\end{tabular}

Regardless of the frequency of occurrence, the species had a wide distribution in the study area, except for L. themistoides, which were only found in stations of the Transect B and Desventuradas Islands. T. fusca and $H$. stephenseni had a relatively homogeneous abundance. At the same time, $33 \%$ of the L. schizogeneios specimens were captured at station 7 (Transect A), a sector in which the SASW has maximum participation in the first $50 \mathrm{~m}$ depth (Fig. 2a). Vibilia armata and Simorhynchotus antennarius, although they are species with numerical dominance and frequency of occurrence lower than those of the species mentioned above, also had their highest concentrations $\left(>10\right.$ ind $\left.100 \mathrm{~m}^{-3}\right)$ in the same sector (St. 4 and 7), the only place where specimens of Lestrigonus bengalensis were captured.

The highest concentrations of $P$. semilunata and $E$. armata $\left(>10\right.$ ind $\left.100 \mathrm{~m}^{-3}\right)$ were found in the northern part of Transect B, a sector in which STSW have their greatest participation.

Acanthoscina acanthodes, Scina stenopus, Anchylomera blossevillei, Paratyphis maculatus, and Amphithyrus bispinosus were sparsely abundant $(<10$ ind $100 \mathrm{~m}^{-3}$ ). They were captured only in stations near Desventuradas Islands, as were Scina stebbingi, Scina submarinata, and Amphithyrus sculpturatus, which were found in stations of the northern part of Transect B.

Phronima pacifica and low dominance and frequency of occurrence (Table 3) were only captured in stations near the R. Crusoe Island and between San Félix and San Ambrosio islands. At the same time, Phronimopsis spinifera and Rhabdosoma armatum were found only in one station, located next to the R. Crusoe Island (St. 13 and 36, respectively). 
Table 3. Abundance, dominance, and amphipod's specific occurrence frequency.

\begin{tabular}{|c|c|c|c|c|c|c|c|}
\hline Species & $\begin{array}{l}\text { Abundance } \\
\text { (ind } 100 \mathrm{~m}^{-3} \text { ) }\end{array}$ & $\begin{array}{c}\text { Dominance } \\
(\%)\end{array}$ & $\begin{array}{c}\text { Frequency } \\
(\%)\end{array}$ & Species & $\begin{array}{l}\text { Abundance } \\
\text { (ind } 100 \mathrm{~m}^{-3} \text { ) }\end{array}$ & $\begin{array}{c}\text { Dominance } \\
(\%)\end{array}$ & $\begin{array}{c}\text { Frequency } \\
(\%)\end{array}$ \\
\hline Acanthoscina acanthodes & 1 & 0.1 & 1.6 & Phronimella elongata & 29 & 2.6 & 26.6 \\
\hline Scina stenopus & 1 & 0.1 & 1.6 & Anchylomera blossevillei & 2 & 0.2 & 3.1 \\
\hline Scina borealis & 5 & 0.4 & 7.8 & Primno macropa & 27 & 2.4 & 28.1 \\
\hline Scina crassicornis & 3 & 0.3 & 4.7 & Primno brevidens & 41 & 3.6 & 43.8 \\
\hline Scina curvidactyla & 10 & 0.9 & 12.5 & Primno latreillei & 11 & 1.0 & 15.6 \\
\hline Scina latifrons & 5 & 0.4 & 4.7 & Phrosina semilunata & 92 & 8.1 & 59.4 \\
\hline Scina stebbingi & 4 & 0.4 & 6.3 & Anapronoe reinhardti & 2 & 0.2 & 3.1 \\
\hline Scina submarginata & 3 & 0.3 & 4. & Tryphana malmii & 24 & 2.1 & 26.6 \\
\hline Scina tullbergi & 16 & 1.4 & 15.6 & Brachyscelus crusculum & 13 & 1.1 & 17.2 \\
\hline Lanceola pacifica & 5 & 0.4 & 7.8 & Lycaeopsis themistoides & 39 & 3.4 & 29.7 \\
\hline Vibilia armata & 32 & 2.8 & 35.9 & Eupronoe minuta & 41 & 3.6 & 26.6 \\
\hline Vibilia stebbingi & 29 & 2.6 & 31.3 & Eupronoe armata & 184 & 16.3 & 87.5 \\
\hline Vibilia australis & 6 & 0.5 & 7.8 & Parapronoe crustulum & 16 & 1.4 & 12.5 \\
\hline Paraphronima gracilis & 17 & 1.5 & 18.8 & Parapronoe parva & 6 & 0.5 & 6.3 \\
\hline Laxohyperia vespuliformis & 16 & 1.4 & 20.3 & Lycaea serrata & 3 & 0.3 & 4.7 \\
\hline Themistella fusca & 58 & 5.1 & 60.9 & Simorhynchotus antennarius & 27 & 2.4 & 20.3 \\
\hline Hyperioides longipes & 11 & 1.0 & 9.4 & Oxycephalus piscator & 4 & 0.4 & 4.7 \\
\hline Themisto gaudichaudii & 1 & 0.1 & 1.6 & Streetsia porcella & 8 & 0.7 & 10.9 \\
\hline Hyperietta stephenseni & 64 & 5.7 & 48.4 & Calamorhynchus pellucidus & 35 & 3.1 & 43.8 \\
\hline Hyperietta stebbingi & 15 & 1.3 & 15.6 & Glossocephalus milneedwardsi & 1 & 0.1 & 1.6 \\
\hline Phronimopsis spinifera & 1 & 0.1 & 1.6 & Rhabdosoma armatum & 1 & 0,1 & 1.6 \\
\hline Lestrigonus bengalensis & 2 & 0.2 & 3.1 & Paratyphis maculatus & 1 & 0.1 & 1.6 \\
\hline Lestrigonus crucipes & 38 & 3.4 & 32.8 & Tetrathyrus forcipatus & 6 & 0.5 & 7.8 \\
\hline Lestrigonus schizogeneios & 69 & 6.1 & 34.4 & Amphithyrus bispinosus & 1 & 0.1 & 1.6 \\
\hline Phronima curvipes & 29 & 2.6 & 37.5 & Amphithyrus sculpturatus & 5 & 0.4 & 7.8 \\
\hline Phronima sedentaria & 25 & 2.2 & 26.6 & Hemityphis tenuimanus & 29 & 2.6 & 34.4 \\
\hline Phronima pacifica & 8 & 0.7 & 7.8 & Parascelus edwardsi & 9 & 0.8 & 12.5 \\
\hline
\end{tabular}

Anapronoe reinhardti was captured only in stations located around the islands of both archipelagos (St. 22 and 58). In contrast, Tetrathyrus forcipatus was captured in Transect B stations and in the Juan Fernández Archipelago (St. 28, 43, 47, and 50).

We found that the species with the lowest abundance and frequency could be associated with defined geographical areas. Simultaneously, Vibilia armata, V. stebbingi, Lestrigonus crucipes, Hyperietta stephenseni, Phronima sedentaria, Primno brevidens, Calamorhynchus pellucidus, and Hemityphis tenuimanus, which were collected in more than $30 \%$ of the stations (Table 1), did not have a defined distribution pattern. Although the greatest total abundances of amphipods were found in sampled stations at night, the species' abundance had no relation to the sampling hours. Lestrigonus bengalensis, Phronimopsis spinifera, Paratyphis maculatus, Rhabdosoma armatum, and Amphithyrus bispinosus were only found in stations sampled in darkness hours; all of them with low abundance and frequency (Table 3). The first two were only found in the stations of the Transect A (St. 5, 7, and 13, respectively), while Rhabdosoma armatum was only captured at one station of R. Crusoe Island.

Acanthoscina acanthodes, Scina stebbingi, S. submarginata, Hyperioides longipes, Anchylomera blossevillei, Parapronoe parva, Lycaea serrata, Amphithyrus bispinosus, A. sculpturatus, and Paratyphis maculatus were found in stations in the central and northern part of Transect B and Desventuradas Islands. At the same time, Glossocephalus milneedwardsi was only captured in station 47 (middle part of Transect B), which is the one with the greatest species richness and one with the most diversity and abundance.

The faunal similarity between stations (cluster analysis), which considers all the species identified, did not generate a spatially defined pattern, finding high similarities between geographically distant stations. Mainly due to the presence of low frequency of species $(<10 \%)$ in geographically distant stations (Lanceola pacifica, Scina crassicornis, S. borealis, Vibilia australis, Anapronoe reinhardti, Oxycephalus piscator). 


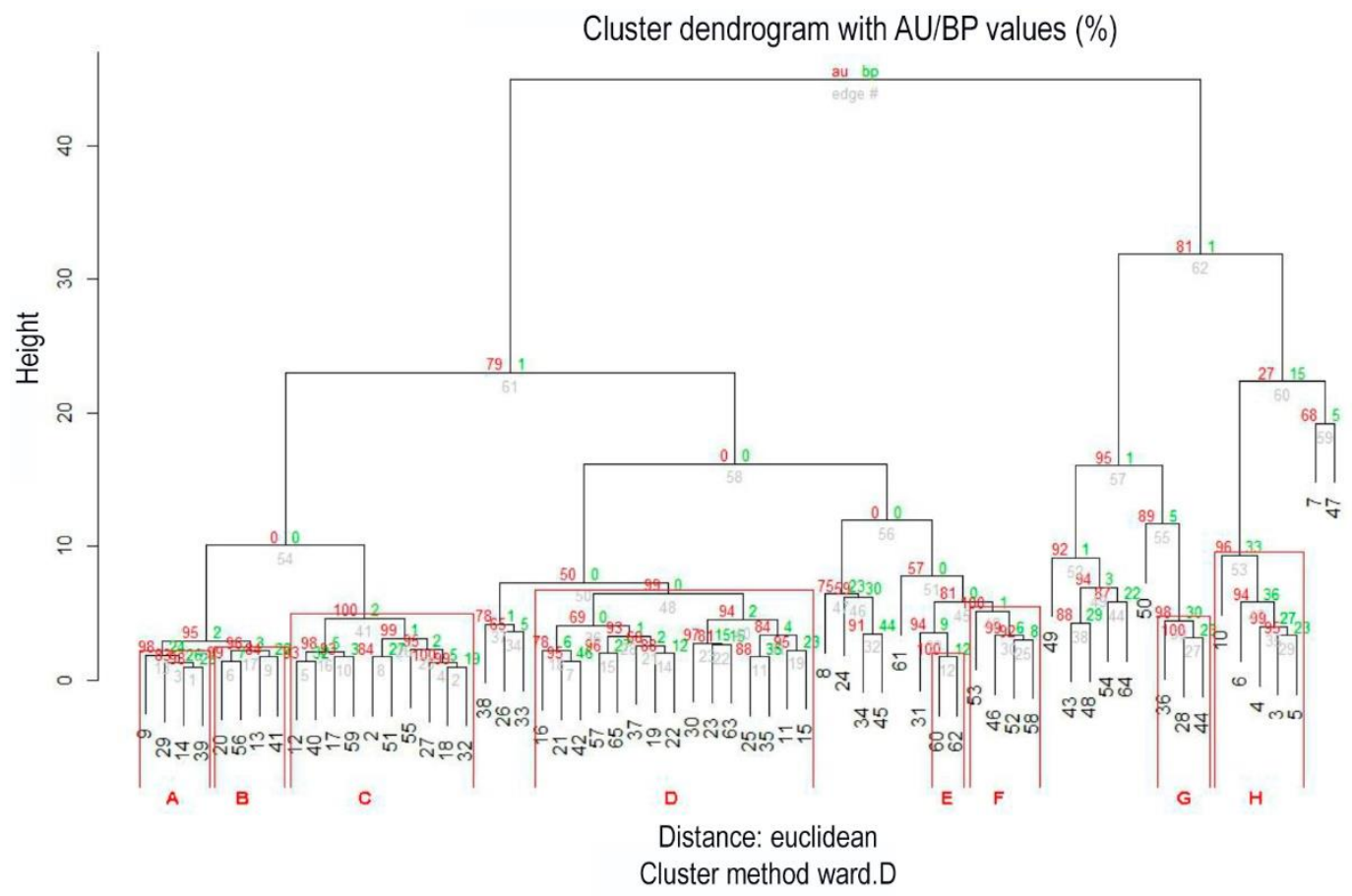

Figure 4. Clusters of amphipod faunal similarity (excluding species of accidental occurrence frequency).

By discarding accidental occurrence frequency species from the analysis, the cluster established nodes at geographically nearby stations. Nodes E and F (100\% faunal similarity), grouped stations near Desventuradas Islands (Fig. 4). Node G (98\% faunal similarity) grouped stations located around the R. Crusoe Island, and node $\mathrm{H}$ (96\% faunal similarity) grouped stations in the eastern half of Transect A. It should be noted that this node did not include station 7, whose indexes were different from those of adjacent stations. In it, two species (Lestrigonus schizogeneios and Simorhynchotus antennarius) accounted for more than $50 \%$ of the amphipods captured. The remaining nodes of fauna similarity greater than $95 \%$ (A, $\mathrm{B}, \mathrm{C}, \mathrm{D})$, grouped geographically distant stations, distributed throughout the sampling area (Fig. 4).

\section{DISCUSSION}

The average abundance of amphipods captured was lower than that reported for the North Pacific and the Gulf of Mexico (Shulenberger 1977, 1980, Gasca 2004), investigations that used the same capture systems (bongo net), and notoriously greater than those reported for in the southeast Pacific (Meruane 1980, Barkhatov \& Vinogradov 1988, Vinogradov 1991). In the last two works, the IKMT net was used, which captures zooplankters of greater mobility.

Of the species found in this study, 96.3\% have been described for the southeastern Pacific by Vinogradov
(1990). Also, the presence of most of the species identified in the study area coincides with that reported for the subtropical sector of the South and North Pacific (Shulenberger 1977, Vinogradov 1990, 1991, Vinogradov et al. 1996, Gasca et al. 2012, Gasca \& Morales-Ramírez 2012), which Vinogradov (1990) and Vinogradov et al. (1996) have defined it as a circumtropical faunal complex.

The highest species richness and abundance of amphipods found in the middle part of Transect A coincide with the highest surface participation of SASW; as well as those of Transect B, corresponds to the northern part of the sampled area, coinciding with the highest percentages of STSW in the first $100 \mathrm{~m}$ of depth.

In the first case (St. 7), the great abundance corresponds mainly to Lestrigonus schizogeneios and Simorhynchotus antennarius $(>50 \%$ of the total amphipods). These cosmopolitan species have been reported for Chile's continental and insular waters (Meruane 1980, 1982, Vinogradov 1990, 1991, Labbé 1999, Véliz 2005). In the second zone, one of the most frequent species was the Phrosina semilunata, common and abundant in tropical, subtropical, and temperate waters, especially in waters near the coast (Vinogradov et al. 1996, Gasca \& Morales-Ramírez 2012). According to Shih \& Chen (1995), it is one of the most abundant hyperiids in the eastern Pacific. 
Eupronoe armata and Themistella fusca, the two species with the highest frequency of occurrence, coincide with the localities where SASW and ESSW predominated in the first $200 \mathrm{~m}$ (Moraga \& Argandoña 2008). Stuck et al. (1980), Zeidler (1992), Vinogradov et al. (1996) indicate that they are surface water species, warm and circumtropical. Bowman (1973) found $T$. fusca in the eastern tropical Pacific and the distribution mentioned above, so its wide distribution and environmental heterogeneity found in this study allow us to infer that they are cosmopolitan species.

Lestrigonus bengalensis and Phronimopsis spinifera were found only in Transect A stations, where SASW predominated superficially, characterized by low temperatures and salinities (Moraga \& Argandoña 2008). These species have been recorded for circumtropical waters, preferably neritic and wide distribution (Stuck et al. 1980, Zeidler 1992, Gasca \& Shih 2001, Gasca 2009, Gasca \& Morales-Ramírez 2012, Valencia et al. 2013, Gasca \& Franco-Gordo 2013).

Hyperioides longipes, Anchylomera blossevillei, Parapronoe parva, Amphithyrus bispinosus, A. sculpturatus, and Paratyphis maculatus were captured only in the sector where the STSW superficially predominated (northern half of the Transect B near Desventuradas Islands). Species that several authors have described for tropical and subtropical waters of the epi and mesopelagic zones (Dick 1970, Stuck et al. 1980, Zeidler 1992, Vinogradov et al. 1996).

The presence and wide geographic distribution of Laxohyperia vespuliformis and Hemityphis tenuimanus represent the southernmost records of them. $L$. vespuliformis has been recorded for the central part of the Pacific Ocean $\left(22^{\circ} \mathrm{N}, 114^{\circ} \mathrm{W}\right)$, Atlantic Ocean $(23-$ $27^{\circ} \mathrm{S}, 41-48^{\circ} \mathrm{W}$ ), China Sea, and the western coast of Baja California Peninsula (Vinogradov et al. 1996, Lima \& Valentín 2001, Lavaniegos 2014). It was found mainly near the Juan Fernández Archipelago, where SASW and ESSW predominate superficially, resembling conditions described by Lima \& Valentin (2001) and Lavaniegos (2014).

Specimens of $H$. tenimanus, also found mainly around the Juan Fernández Archipelago, have been recorded for the tropical Atlantic Ocean (Gasca 2003), in the Nazca Mountain range (Vinogradov et al. 1996), and west of the Baja California Peninsula (Lavaniegos 2014). According to what was described by Zeidler (1998) and Zeidler \& De Broyer (2009), the specimens found in this study correspond to juveniles.

The infraorder Physosomata species are mainly meso and bathypelagic (Shulenberger 1977, Vinogradov 1990, 1991, Shih \& Chen 1995, Gasca 2009), so their presence in nocturnal catches could be indicating their condition as vertical migrators. Only Scina tullbergi and Acanthoscina acanthodes live permanently at depths less than $200 \mathrm{~m}$ (Shulenberger 1977, Vinogradov et al. 1996). The others, only juveniles are found over 200 to $300 \mathrm{~m}$ deep (Vinogradov 1990), as Lanceola pacifica (Bowman \& Gruner 1973, Thurston 1976, Shulenberger 1977, Vinogradov 1990, 1991, Vinogradov et al. 1996). Other species, such as $S$. crassicornis, S. borealis, or $S$. submarginata, regularly climb to the epipelagic zone in darkness hours.

Many species' vertical distribution, their vertical migration, and the sampling restriction to the epipelagic zone $(0-200 \mathrm{~m})$ allow us to assume that more in-depth sampling would increase the species richness of the studied sector, something that has been indicated by Gasca (2009) and Gasca et al. (2012).

The greatest diversities found in the northern part of the study area agree with that described for the oceanic, subtropical, and tropical regions (Vinogradov 1990, 1991). The stations in this sector are in transition zones or borders between two oceanographic systems, in which SASW and STSW concur, inserted in the southeast Pacific anticyclonic gyre (Silva \& Sievers 1973, 1974, Silva \& Konow 1975, Silva 1985, 1992, Vinogradov 1990, 1991, Moraga \& Olivares 1996, Bower et al. 1997).

The literature indicates that the systems associated with subtropical gyres, such as the South Pacific anticyclonic gyre, have low levels of zooplankton biomass and secondary production (Rivera 2003), in addition to relatively high specific diversities (Loeb 1979, Vinogradov 1990, Gibbons et al. 1992). Burridge et al. (2017) pointed out that most zooplankton groups have maximum diversity in subtropical waters. That and hyperiid genera species richness in equatorial areas suggests that the mechanisms that control diversity in this group are different from other zooplankton taxa. Moreover, they could be closely linked to gelatinous zooplankters (Laval 1980, Lavaniegos \& Hereu 2009, Lavaniegos 2014).

Shulenberger (1979) and Gasca (2003) point out that hyperiid amphipods form aggregations with welldefined distribution patterns so that neritic and oceanic hyperiid communities are different. As has been seen in the nodes' formation that grouped stations located in the northern part of Transect B, around Desventuratdas Islands, R. Crusoe Island, and the group of stations in the eastern half of Transect A. The more remarkable faunal similarity of these cluster nodes, which joined geographically nearby stations, was generated by the presence and abundance of wide distribution species with those of distribution associated with defined water 
masses. These community conformations have been reported by Valencia et al. (2013).

The node with the lowest faunal similarity was integrated by two geographically distant stations, where the highest amphipods' abundances were found (stations 7 and 47). The highest participation percentages of cold and warm surface water masses were detected (SASW and STSW, respectively), explaining their low faunal similarity. In station 7, Lestrigonus schizogeneios and Simorhynchotus antennarius predominated, species been reported for cold waters (Gasca 2003). In station 47, Phrosina semilunata and Eupronoe armata predominated temperate or warm waters species (Vinogradov et al. 1996, Gasca \& Morales-Ramírez 2012).

Cushman (1923), Wooster \& Sievers (1970), Sievers \& Silva (1975), and Fuenzalida et al. (2007) point out that the oceanographic dynamics of the study area is influenced by a longitudinal currents system and countercurrents that would be consequences of the superficial and coastal drift generated by water masses geostrophic movement. Furthermore, Hormazabal et al. (2004) indicated that in off Chile's central zone (29$39^{\circ} \mathrm{S}$ ), eddies of great kinetic energy are periodically generated. Therefore, the oceanographic dynamics of the study area, the sensitivity of hyperiid amphipods to environmental variations (Lavaniegos \& Ohman 1999, Lavaniegos \& Hereu 2009, Valencia \& Giraldo 2009, Lavaniegos 2014, Zhang et al. 2014), and how rare hyperiid are in the epipelagic zone during daytime hours (Gasca \& Shih 2001), explains the low abundance, species richness and segregation of groups in this extensive and oceanographically heterogeneous study area.

\section{ACKNOWLEDGMENTS}

The authors thank the National Oceanographic Committee (CONA) and the CIMAR Program Executive Committee to carry out the research project. To the scientist chief of the research vessel AGOR 60 "Vidal Gormaz" and his crew. To José Iván Sepúlveda for the translation of this paper.

\section{REFERENCES}

Barkhatov, V. \& Vinogradov, M. 1988. Hyperiid amphipods, subantarctic and adjacent areas on the central part of the Pacific. In: Vinogradov, M.E. \& Flint, M.V. (Eds.). Subantarctic zone ecosystems in the Pacific. Nauka, Moscow, pp. 228-245 (in Russian).

Bocher, P., Cherel, Y., Labat, J., Mayzaud, P., Razouls, S. \& Jouventin, P. 2001. Amphipod-based food web:
Themisto gaudichaudii caught in nets and by seabirds in Kerguelen waters, southern Indian Ocean. Marine Ecology Progress Series, 223: 261-276.

Bodenheimer, F. 1955. Précis d'écologie animale. Payot, Paris.

Bower, A.S., Armi, L. \& Ambar, I. 1997. Lagrangian observations of meddy formation during a Mediterranean undercurrent seeding experiment. Journal of Physical Oceanography, 27: 2545-2575.

Bowman, T. 1973. Pelagic amphipods of the genus Hyperia and closely relates genera (Hyperiidea: Hyperiidae). Smithsonian Contributions to Zoology, 136: 1-76.

Bowman, T. \& Gruner, H. 1973. The families and genera of Hyperiidea (Crustacea: Amphipoda). Smithsonian Contributions to Zoology, 146: 1-60.

Brandhorst, W. 1971. Condiciones oceanográficas estivales frente a la costa de Chile. Revista de Biología Marina, Valparaíso, 14: 45-84.

Burridge, A., Tump, M., Vonk, R., Goetze, E. \& Peijnenburg, K. 2017. Diversity and distribution of hyperiid amphipods along a latitudinal transect in the Atlantic Ocean. Progress in Oceanography, 158: 224235.

Cushman, R. 1923. The oceanography of the Peruvian littoral with reference to the abundance and distribution of marine life. Geographical Review, 13: 64-85.

Croxall, J. 2006. Monitoring preditor-prey interactions using multiple predator species: the South Georgia experience. In: Boyd, I.L., Wanless, S. \& Camphuysen, C.J. (Eds.). Top predators in marine ecosystems: their role in monitoring and management. Cambridge University Press, Cambridge, pp. 157-176.

Dick, R.I. 1970. Hyperiidae (Crustacea: Amphipoda) keys to South African genera and species, and a distribution list. Annals of the South African Museum, 57: 25-86.

Fuenzalida, R., Schneider, W., Blanco, J., Garcés-Vargas, J. \& Bravo, L. 2007. Sistema de corrientes Chile-Perú y masas de agua entre Caldera e Isla de Pascua. Ciencia y Tecnología del Mar, 30: 5-16.

Gasca, R. 2003. Hyperiid amphipods (Crustacea: Peracarida) in relation to a cold-core ring in the Gulf of Mexico. Hydrobiologia, 510: 115-124.

Gasca, R. 2004. Distribution and abundance of hyperiid amphipods in relation to summer mesoscale features in the Southern Gulf of Mexico. Journal of Plankton Research, 26: 993-1003.

Gasca, R. 2009. Hyperiid amphipods (Crustacea: Peracarida) in Mexican waters of the Pacific Ocean. Pacific Science, 63: 83-95.

Gasca, R. \& Franco-Gordo, C. 2013. Anfípodos Hyperiidea de la costa sur de Jalisco y Colima. In: 
Franco-Gordo, C. (Ed.). Inventario de biodiversidad de la costa sur de Jalisco y Colima. Vol. 1. Universidad de Guadalajara, Guadalajara, pp. 69-78.

Gasca, R. \& Morales-Ramírez, A. 2012. Anfípodos hiperídeos (Crustacea: Peracarida) del Parque Nacional Isla del Coco, Costa Rica, Pacífico Tropical Oriental. Revista de Biología Tropical, 60: 223-233.

Gasca, R. \& Shih, C.T. 2001. Hyperiid amphipods from surface waters of the western Caribbean Sea (1991). Crustaceana, 74: 489-499.

Gasca, R., Franco-Gordo, C., Godínez-Domínguez, E. \& Suárez-Morales, E. 2012. Hyperiid amphipod community in the Eastern Tropical Pacific before, during, and after El Niño 1997-1998. Marine Ecology Progress Series, 455: 123-139.

Gibbons, M., Stuart, V. \& Verheye, H. 1992. Trophic ecology of carnivorous zooplankton in the Benguela. South African Journal of Marine Science, 12: 421-437.

Harbison, G.R., Biggs, D.C. \& Madin, L.P. 1977. The associations of Amphipoda Hyperiidea with gelatinous zooplankton-II. Associations with Cnidaria, Ctenophora and Radiolaria. Deep-Sea Research, 24: 465488.

Hormazabal, S., Shaffer, G. \& Leth, O. 2004. Coastal transition zone off Chile. Journal of Geophysical Research, 109: C01021. doi: 10.1029/2003JC001956

Hurt, C., Haddock, S.H.D. \& Browne, W.E. 2013. Molecular phylogenetic evidence for the reorganization of the hyperiid amphipods, a diverse group of pelagic crustaceans. Molecular Phylogenetics and Evolution, 67: 28-37.

Klimpel, S. \& Rückert, S. 2005. Life cycle strategy of Hysterothylacium aduncum to become the most abundant anisakid fish nematode in the North Sea. Parasitology Research, 97: 141-149.

Klimpel, S., Palm, H., Busch, M. \& Kellermanns, E. 2008. Fish parasites in the bathyal zone: the halosaur Halosauropsis macrochir (Günther, 1878) from the Mid-Atlantic Ridge. Deep-Sea Research II, 55: 229235.

Kosenok, N.S. \& Naidenko, S.V. 2008. Feeding and daily ration of the chum salmon Oncorhynchus keta in the Western Bering Sea in the summer-fall of 2004. Russian Journal of Marine Biology, 34: 17-27.

Koval, M.V. \& Batischeva, N.A. 2003. Composition and distribution of macroplankton in the east-coast waters of Kamchatka during fall period, 2000 and 2002. Kamchatka Research Institute of Fisheries \& Oceanography (KamchatNIRO), Petropavlovsk-Kamchatsky, NPFAC 675: 28 pp.

Labbé, J. 1999. Composición, distribución y abundancia de los anfípodos hipéridos (Amphipoda: Hyperiidae) frente a la costa de Concepción $\left(36^{\circ} 06^{\prime} \mathrm{S}-37^{\circ} 00^{\prime} \mathrm{S}\right)$. Tesis de Biología Marina, Universidad Católica del Norte, Coquimbo.

Laval, P. 1980. Hyperiid amphipods as crustacean parasitoids associated with gelatinous zooplankton. Oceanography and Marine Biology, 18: 11-56.

Laval, P. 2001. A dedicated soft-real simulation of salp warm in ADA 95. SCS Europe Bvba. Proceedings of the 13th European Simulation Symposium and Exhibition, ESS'2001 (Simulation in Ecology Workshop), Marseille, France, pp. 499-503.

Lavaniegos, B.E. 2014. Pelagic amphipod assemblage associated with subarctic water off the west coast of the Baja California Peninsula. Journal of Marine Systems, 132: 1-12.

Lavaniegos, B.E. \& Hereu, C. 2009. Seasonal variation in hyperiid amphipods and influence of mesoscale structures off Baja California. Marine Ecology Progress Series, 394: 137-152.

Lavaniegos, B.E. \& Ohman, M.D. 1999. Hyperiid amphipods as indicators of climate change in the California Current. In: Schram, F.R. \& Von VaupelKlein, J.C. (Eds.), Crustaceans and the biodiversity crisis. Proceedings of the Fourth International Crustacean Congress, Amsterdam, Netherlands, Vol. I. Brill, Leiden, pp. 489-509.

Lima, M. \& Valentin, J. 2001. Preliminary results to the holistic knowledge of the amphipods hyperiids faunal composition off the Brazilian coast. Journal of Plankton Research, 23: 469-480.

Loeb, V. 1979. Larval fishes in the zooplankton community of the North Pacific Central Gyre. Marine Biology, 53: 173-191.

Mamayev, I.O. 1975. Temperature-salinity analysis of world ocean waters. Elsevier, Amsterdam.

Meruane, J. 1979. Contribución a la taxonomía y ecología de los anfípodos hypéridos encontrados frente a punta Curaumilla, Valparaíso. Tesis de Licenciatura, Universidad Católica de Valparaíso, Valparaíso.

Meruane, J. 1980. Anfípodos hypéridos encontrados frente a la costa de Valparaíso. Aspectos taxonómicos. Investigaciones Marinas, Valparaíso, 8: 145-182.

Meruane, J. 1982. Anfípodos hypéridos recolectados en las aguas circundantes a las islas Robinson Crusoe y Santa Clara. Enero 1974. Investigaciones Marinas, Valparaíso, 10: 35-40.

Mesias, J., Matano, R. \& Strub, P.T. 2003. Dynamical analysis of the upwelling circulation off central Chile. Journal of Geophysics Research, 108: 3085. doi: 10.1029/2001JC001135

Moraga, J. \& Argandoña, W. 2008. Condiciones oceanográficas alrededor del Archipiélago Juan 
Fernández e islas San Félix-San Ambrosio. Ciencia y Tecnología del Mar, 31: 137-148.

Moraga, J. \& Olivares, J. 1996. Hidrografía del área costera de Isla de Pascua, Mayo 1994. Ciencia y Tecnología del Mar, 19: 47-56.

Palma, S. \& Kaiser, K. 1993. Plancton marino de aguas chilenas. Ediciones Universitarias de Valparaíso, Valparaíso.

Rivera, J. 2003. Distribución y abundancia relativa de larvas de crustáceos decápodos entre Caldera $\left(27^{\circ} 00^{\prime} \mathrm{S}\right.$, $\left.70^{\circ} 52^{\prime} \mathrm{W}\right)$ e Isla de Pascua (2700'S, $\left.109^{\circ} 40^{\prime} \mathrm{W}\right)$ durante octubre de 1999. Tesis de Biología Marina, Universidad Arturo Prat, Iquique.

Schneider, W., Fuenzalida, R., Núñez, R., Garcés-Vargas, J., Bravo, L. \& Figueroa, D. 2007. Discusión del sistema de la corriente de Humboldt y masas de agua en la zona norte y centro de Chile. Ciencia y Tecnología del Mar, 30: 21-36.

Shih, C.T. \& Chen, Q. 1995. Zooplankton of China seas. The Hyperiidea (Crustacea: Amphipoda). China Ocean Press, Beijing.

Shih, C.T. \& Hendrycks, E.A. 2003. A new species and new records of the genus Vibilia Milne Edwards, 1830 (Amphipoda: Hyperiidea: Vibiliidae) occurring in the eastern Pacific Ocean. Journal of Natural History, 37: 253-296.

Shulenberger, E. 1977. Hyperiid amphipods from the zooplankton community of the North Pacific Central Gyre. Marine Biology, 42: 375-385.

Shulenberger, E. 1979. Distributional pattern and niche separation among North Pacific hyperiid amphipods. Deep-Sea Research, 26: 293-315.

Shulenberger, E. 1980. Factor analyses of a hyperiid amphipod assemblage from the North Pacific Central Gyre. Marine Ecology Progress Series, 2: 109-120.

Sievers, H. 1975. Condiciones oceanográficas de verano de las aguas circundantes a las islas Robinson Crusoe y Santa Clara. Investigaciones Marinas, Valparaíso, 6: 49-72.

Sievers, H. \& Silva, N. 1975. Masas de agua y circulación en el Océano Pacífico Sudoriental. Latitudes $18^{\circ} \mathrm{S}$ $33^{\circ} \mathrm{S}$ (Operación Oceanográfica MARCHILE VIII). Ciencia y Tecnología del Mar, 1: 7-67.

Silva, N. 1985. Algunas características físicas y químicas de las masas de agua alrededor de las islas Robinson Crusoe y Santa Clara. Investigaciones Marinas, Valparaíso, 6: 35-41.

Silva, N. 1992. Condiciones oceanográficas alrededor de la Isla de Pascua durante la primavera de 1979. Ciencia y Tecnología del Mar, 15: 21-30.

Silva, N. \& Konow, D. 1975. Contribución al conocimiento de las masas de agua en el Pacífico Sudoriental. Expedición Krill. Crucero 3-4, Julio-
Agosto 1974. Revista de la Comisión Permanente del Pacífico Sur, 3: 63-75.

Silva, N. \& Neshyba, S. 1979. Masas de agua y circulación geostrófica frente a la costa de Chile austral. Instituto Antártico Chileno, Serie Científica, 25-26: 5-32.

Silva, N. \& Sievers, H. 1973. Condiciones oceanográficas de primavera y otoño de las aguas circundantes a las islas Róbinson Crusoe y Santa Clara. Investigaciones Marinas, Valparaíso, 4: 158-179.

Silva, N. \& Sievers, H. 1974. Masas de agua, velocidad geostrófica y transporte de volumen entre Valparaíso e isla Robinson Crusoe (Océano Pacífico Sudoriental). Revista de la Comisión Permanente del Pacífico Sur, 2: 102-120.

Silva, N. \& Sievers, H. 1981. Masas de agua y circulación en la región de la rama costera de la corriente de Humboldt. Latitudes $18-33^{\circ} \mathrm{S}$ (Operación Oceanográfica MARCHILE X-ERFEN I). Ciencia y Tecnología del Mar, 5: $5-50$.

Silva, N. \& Sievers, H. 1983. Masas de agua y circulación en la región de la rama costera de la corriente de Humboldt. Latitudes $18^{\circ} \mathrm{S}-33^{\circ} \mathrm{S}$ (Operación Oceanográfica MARCHILE XI-ERFEN II). Ciencia y Tecnología del Mar, 7: 47-84.

Stebbing, T. 1888. Report on the Amphipoda collected by H.M.S. Challenger during the years 1873-1876. Zoology, 29: 1-1737.

Stuck, K.C., Perry, H.M. \& Fish, A.G. 1980. New records of Hyperiidea (Crustacea: Amphipoda) from the northcentral Gulf of Mexico. Gulf Research Reports, 6: 359370 .

Thurston, M.H. 1976. The vertical distribution and diurnal migration of the crustacea amphipoda collected during the Sond Cruise, 1965: II. The Hyperiidea and general discussion. Journal of the Marine Biological Association of the United Kingdom, 56: 383-470.

Valencia, B. \& Giraldo, A. 2009. Hipéridos (Crustacea: Amphipoda) en el sector norte del Pacífico oriental tropical colombiano. Latin American Journal of Aquatic Research, 37: 265-273.

Valencia, B., Lavaniegos, B., Giraldo, A. \& RodríguezRubio, E. 2013. Temporal and spatial variation of hyperiid amphipod assemblages in response to hydrographic processes in the Panama Bight, eastern tropical Pacific. Deep Sea Research I, 73: 74-61.

Vaske, T. \& Castello, J. 1998. Conteúdo estomacal da albacora-laje Thunnus albacares, durante o inverno e primavera no Sul do Brasil. Revista Brasileira de Biologia, 58: 639-647.

Véliz, C. 2005. Anfípodos (Crustacea: Amphipoda: Hyperiidea) recolectados entre Valparaíso, Archipiélago de Juan Fernández e Islas Desventuradas 
(Crucero CIMAR VI). Tesis de Biología Marina, Universidad Católica del Norte, Coquimbo.

Vinogradov, G. 1990. Pelagic amphipods (Amphipoda, Crustacea) from the south-eastern Pacific. Academic of Sciences of the URSS. Transactions of the Shirshov of Oceanology, 124: 27-104 (in Russian).

Vinogradov, G. 1991. Hyperiid amphipods in the eastern part of the South Pacific Gyre. Marine Biology, 109: 259-265.

Vinogradov, G. 1999. Amphipoda. In: Boltovskoy, D. (Ed). South Atlantic zooplankton. Backhuys Publishers, Leiden, pp. 1141-1240.

Vinogradov, M., Volkov, A. \& Semenova, T. 1996. Hyperiids amphipods (Amphipoda, Hyperiidea) of the world oceans. Science Publishers, New York.

Wooster, W. \& Sievers, H. 1970. Seasonal variations of temperature, drift, and heat exchange in surface waters off the west coast of South America. Limnology and Oceanography, 15: 595-605.

World Register of Marine Species (WoRMS). WoRMS editorial board. 2020. [http://www.marinespecies.org]. Reviewed: October 4, 2019.

Zeidler, W. 1992. Hyperiid amphipods (Crustacea: Amphipoda: Hyperiidea) collected recently from eastern Australian waters. Records of the Australian Museum, 44: 85-133.

Zeidler, W. 1998. Pelagic amphipods (Crustacea: Amphipoda: Hyperiidea) collected from eastern and southeastern Australian waters by the CSIRO research vessel "Warreen" during the years 1938-1941. Records of the Australian Museum Monograph Series, 4: $1-143$.

Received: 4 December 2019; Accepted: 10 November 2020
Zeidler, W. 2000. Systematic studies of pelagic hyperiidean amphipods Infraorder Physocephalata (Crustacea: Amphipoda: Hyperiidea). Ph.D. Thesis, Universidad of Adelaide, Adelaide.

Zeidler, W. 2003. A review of the hyperiidean amphipod superfamily Vibilioidea Bowman and Gruner, 1973 (Crustacea: Amphipoda: Hyperiidea). Zootaxa, 280: 1104.

Zeidler, W. 2004. A review of the families and genera of the hyperiidean amphipod superfamily Phronimoidea Bowman \& Gruner, 1973 (Crustacea: Amphipoda: Hyperiidea). Zootaxa, 567: 1-66.

Zeidler, W. \& De Broyer, C. 2009. Catalogue of the Hyperidean Amphipoda (Crustacea) of the Southern Ocean with distribution and ecological data. In: De Broyer, C. (Ed.). Census of Antarctic marine life, synopsis of the Amphipoda of the Southern Ocean. Institut Royal des Sciences Naturelles de Belgique, 79: $1-103$.

Zhang, W., Lin, Y., He, C., Cao, W., Huang, J., Zheng, L., Yang, W. \& Wang, Y. 2014. Hyperiid amphipod communities and the seasonal distribution of water masses in eastern Beibu Gulf, South China Sea. Aquatic Biology, 20: 209-217. doi: 10.3354/ab00556 